\title{
RECLAIMING/RENAMING HISTORIES IN CONTEMPORARY LITERATURE, ART, AND CULTURE
}

Marija Krivokapić, University of Montenegro, marija13a@gmail.com

Aleksandra Nikčević Batrićević, University of Montenegro,

alexmontenegro@t-com.me

Nina Sirković, University of Split, nsirkov@fesb.hr

10.31902/fll.26.2019.1

UDK 82.09:930.85

The papers collected in this issue were originally presented at the XIV International Conference on Anglo-American Studies, titled Reclaiming/Renaming Histories, which took place at the Faculty of Philology, University of Montenegro, in June 2018.

Our research discusses exploitation of history in the works of literature, art, and in culture in general, produced in the course of the Twentieth and Twenty-First century. Understanding the difficulty of separating literary text from interpretative practice, as well as of separating theory from moral and ideological inflows, the scholars gathered here do not only unavoidably read literature, art, and culture with a wide historical and social background, but also want to participate in the communication about the perpetuation of master narratives. In particular, they are giving voice in support to the marginalized, predominantly racialized, gendered, politicized, and essentialized, as well otherwise socially, economically, and psychologically excluded, in their effort to claim right of selfdetermination and their distinct stories of their past.

As our primary focus is on how histories are being built and rebuilt, i.e. renamed and reclaimed, we understand that every historical narrative is, as Michel-Rolph Trouillot says in Silencing the Past: Power and the Production of History (2015), "a particular bundle of silences" (27) due to the uneven distribution of power, between its subjects and its objects, present in the four crucial reciprocal moments of historical production:

the moment of fact creation (the making of sources); the moment of fact assembly (the making of archives); the moment of fact retrieval (the making of narratives); and the moment of retrospective significance (the making of history in the final instance). (26)

Thus, while reading the Twentieth- and the Twenty-First century productions of literature, art, and culture, we discuss diverse discourses, such as political, 
ethical, racial, ethnic, gender, sexual, etc., while involving a variety of interpretative strategies, hermeneutic, linguistic, psychoanalytic, semiotic, feminist, poststructuralist, postcolonial, to point to historicity of texts that is always actualized by readers in different epochs. We also assume that this actualization is never subjective and direct, but is forced by a larger social context. On this basis, we are aware of the emerging voices that are disturbing the solipsism of a one cultural discourse, asserting their right over the production of meaning, while also clearly understanding, and building upon, their participation in the symbolical tradition.

We also consider personal histories, i.e. how events are remembered, how past events become restructered in memory, in reminiscences, in diaries; what personal, social, and cultural conditions effect their reordering; what are the by-products of these processes, and what are the intentions and potentials of remembering and retelling of these stories.

Therefore, our intention is to underline the ideological relations between texts in consideration and the historical reality, how historical reality becomes the subject of fabulation and ideologization, and how, at the same time, these agencies are depicted and subverted in literature and art.

As Dalibor Kesić discusses in his paper "From Intersemiotic to Intertextual - a Historical Serendipity," texts, histories, media, and works of art often overlap producing an active space of meanings. Examining works of the past, From Shakespeare to Kurosawa and from Cicero to Jerome, which cross the borders of disciplines, nations, languages, and media, Kesić shows how they are perceived differently outside of their time, metamorphose, ie. "undergo an intersemiotic transformation," to accommodate the beliefs of different eras, yet without losing their originality and mastery.

Tom Phillips' paper "Significant insignificances: Winston Smith's Diary and Other Reclaimed Histories" proposes that an act of storytelling is always potentially engaged in the process of reclaiming and renaming histories. Phillips gives example of George Orwell's novel 1984 and its prominent theme that "[w] ho controls the past controls the future. Who controls the present controls the past," juxtaposing it to an individual desire to write a diary and thus tell an autobiographical story as a socially subversive act. After discussing Orwell's 1984 as "a dystopian 'renaming' of Britain in 1984," the paper looks into Charles Olson's Maximus Poems as "counter-historical texts," which reveal the construction of the American identity after World War II, and into Georgi Gospodinov's Natural Novel as an exploration of the the nature of storytelling in the chaning historical contexts of post-communist Bulgaria.

In "When Yours and Mine Are (Not) Ours: Reclaiming Personal and National Histories in Tim Butcher's The Trigger: Hunting the Assassin Who Brought the World to War" Željka Babić relies on on the postulates of Peter Hanenberg's 
(2014) posits on intramental translation to discuss how linguistic traits of the said literary text reveal the author's attitude towards the depicted cultural and historical events, i.e. to show certain parallelism between individual and group histories. By giving a personal account of the time, the author uncovers the events that ignited "the bloodiest conflict in the known history of the time."

In "And Action!: Reinterpretation and Simulation of History Through Film in DeLillo's Americana and Libra," relying on Linda Hutcheon, Slađana Stamenković discusses history and reality as a whole as constructs of a particular way of recording and a particular media. Don DeLillo's novels Americana and Libra introduce films as specific textual recordings of past, i.e. fabrication of the past. The paper explores how in both novels the film-makers are writing themselves into important national narratives.

"Re-imagining Histories, Re-inventing the Self in Ian McEwan's Atonement," by Vanja Vukićević Garić classifies the said novel as a postmodern realistic prose or a "restorative metafiction" (O'Hara) and discusses McEwan's claim that "imagining what it is like to be someone other than yourself is at the core of our humanity." The paper focuses on the extent to which imagination can "re-generate, amend, and meaningfully extend personal histories," as well as on the issue of one text's ethical right ot do so.

Senka Božić-Vrbančić's paper "Contested Sites of Memory on Tarara in New Zealand" looks at the recording by Croatian immigrants in collonial and postcolonial New Zealand and their communication with equally denounced and marginalized Maori on the northern gumfileds. The stories that are analized echo the "processes of differentiation and power relations," how they are retroactively constructed, and how the meaning of tradition is restructured with each political transformation.

"Occasionally, He's a Somniaticidal Maniac: Stephen Graham Jones Reclaims Home and History," by Theodore C. Van Alst assumes an environmental activist claim and elaborates how the stories we tell might be detrimental to the mother Earth by the way they "remold, reshape, reclaim and remake [...] our histories and homes." The paper addresses some of Stephen Graham Jones's prolific works, including Sterling City and Chapter Six to examine how stories shape the existing and the future homes, i.e. how they influence the future history.

Maja Muhić opens her paper "Reclaiming Women's Perspective: Feminist Anthropology and the Androcentric Bias," by discussing an importan anthropological turn that developed in the 1980s, which influenced a perception of the discipline as one "writing a culture rather than understanding it from the insider's perspective," frustrating thus the necessary dialogical relation with its own subjects of study. It is, therefore, important to revisit the predominantly male biased androcentric understanding of cultures and turn to feminist anthropology and look into some prominent women anthropologists' work that has been excluded from the canon for a long time. 
In "Reclaiming Histories/Rewriting Destinies: Mrs. Woolf and Orlando in Unearthing the Buried," Milica Nenezić also assumes that there are different histories that affect the fate of mankind and require reexamination. She uses insights from philosophy, feminist literary criticism and post-structural theories to discuss how our recordings of events determines both the future and our changeable existence. She sees in Virginia Woolf's novel Orlando a literary text that serves this purpose most effectively.

"Changing the Pattern: Reclaiming History, Constructing Herstory in Margaret Atwood's Aalias Grace," by Ana Sentov, discusses how the socially marginalized are often silenced, being never given the chance to tell their own version of their past. On the example of the novel Alias Grace, we are shown how the basic structures of a male dominated society, such as the law, the medical profession, the church, and the media, portray a woman immigrant and a member of a working class as an outsider and always a potentially dangerous element. Revealing these forces, however, do not leave the reader with a final and definite knowledge of who Grace Marks really is, whether she commited the crime she is imprisoned for or whether she is really a lunatic. The herstory that Grace attempts to reclaim remains "her fictive memoir."

Another Atwood's novel discussed in this issue in The Handmaid's Tale. "Rethinking Personal History and Maintaining Identity - Offred in Margaret Atwood's The Handmaid's Tale," Elena Spirovska also explores how personal histories define identities. Offred's story given to the reader is, actually, a written narrative reconstructed from tapes recorded two centuries after Offred's death and discussed at a scientific conference. We are shown how the dictatorship of Gilead has deprived Offred of her name, past, freedom, and identity, by limiting her identity to that of a child bearer. However, Offred still can think back about her past and her relationships with her mother, husband, and child, which gives her power to build her own story and rethink and recreate herself.

"(Re)claiming English Language Today," by Nadežda Stojković, discusses the historical development of the influence of the English language in numerous contexts globally to show that it can no longer be claimed to belong to the countries from where it originates and that the concept of "standard English," which assumes supremacy of one of its variants may be understood as "yet another facet of [...] neocolonialism and globalization," i.e. as oppressive to the formation and expression of different cultures and localities worldwide. It is, therefore, necessary that the growing community of English users claim their right over their voices. This kind of "writing back" to the colonizer implies neither a rejection of English or taking it completely over from its native speakers, but it actually instigates a further investigation of what ontology this language now embodies and new posibilities of cultural renewals and exchanges. 
In "The Cultural Chronicle and the Historical Reality of Half a Century of Dragan Karadžić's Creative Catharsis," Brankica Bojović looks into a personal history of a painter as recorded on his paintings, involving culturological and creative analyses. Bojović presents the painting as a specific cultural catharsis and a chronicle of the society the artist belongs to, but also calls for new chronological approaches regarding creativity in the Balkan cultural area.

"Art as a Redefinition of History in Praxis Philosophy," by Slađana Kavarić, shows that aesthetics is both "fundamentally historically based" and always requires renewed definitions of historical experience. The importance of this claim comes from the fact that the globalized culture and the technologization of everyday life are oblivious of art as an important agent of self-understanding in the historical context. The paper shows how ideologies impact artisic expression but also how art always questions the boudnaries of understanding.

Predrag Živković's paper "A Manifest of the Endangered Past" approaches the issue of history from a sociological perspective, discussing the culture of memory, claiming how in the post-socialist societies it often functions as a "refuge of forgetfulness" and dangerous agents of constructing a society's identity, while being able to always anew retell, or recreate, a new comfortable past. Živković asks if "it is the way of collective catharsis or a systemic and ideological exorcism, which systematically creates and persecutes all those who do not conform."

We have tried to show how the concept and the nature of history have stood among the burning subjects of the Western thought in the last two centuries. We have opted for an eclectic theoretical approach to how history, historicity of past and present phenomena, historicity of text, and mediated stories of past and present are problematized in the Twentieth and Twenty-First century literature, art, and culture, to be able to more easily develop a conversation with colleagues from a variety of disciplinies in the humanities, interetsed in the ever-changing onthology of human life and being, contemporary society and the global culture we share today.

We are grateful to our friend and colleague, Native American poet and scholar, Distinguished Professor Allison Hedge Coke, from University of Riverside in California, who thought of this challenging topic that brought scholars from around the world to the conference and united us in this issue of Folia linguistica et litteraria. 